\title{
Estimation of post-harvest losses of major fruits in Karnataka- A management appraisal
}

\author{
D.H. MitrannaVAR* and R.A. Yeledalli ${ }^{1}$
}

Extension Edication Unit, U.A.S. (D), Sirsi, UTTAR KANNADA (KARNATAKA) INDIA

${ }^{1}$ Department of Agribusiness Management, University of Agricultural Sciences, DHARWAD (KARNATAKA) INDIA

(Email:mitrudh@rediffmail.com)

\begin{abstract}
SUMMARY :
Agriculture occupies the central place in rural life. The contribution of agriculture towards national income is about 15.5 per cent in 2010-2011 (GOI 2007). Horticultural crops include large varieties of fruits and vegetables, flowers, plantation spice crops, medicinal and aromatic plants, roots and tuber crops. In Karnataka, the total area under fruit crops has increased from 1.41 lakh hectares in 1978-79 to 3.14 lakh hectares in 1998-99 registering a growth of 1.7 to 2.7 per cent. The production of fruit crops has also gone up from. 23.41 lakh tonnes during 1978-79 to 54.50 lakh tonnes in 1998-99 showing an increase of 132.64 per cent. The present study conducted in Karnataka state and aims at estimation of post-harvest losses in major vegetables. The results of the study revealed that the overall loss at different stages was around $60.08 \mathrm{~kg}(13.09 \%)$ in mango. The maximum loss was found to occur at the field level. The overall loss at different stages was around 392.66 $\mathrm{kg}(11.80 \%)$ in banana. The maximum loss was found to occur at the retail level. The overall loss at different stages was around $31.97 \mathrm{~kg}(9.06 \%)$ in citrus. The maximum loss was found to occur at the field level. The overall loss at different stages was around $37.30 \mathrm{~kg}(12.64 \%)$ in guava. The maximum loss was found to occur at the retail level. The overall loss at different stages was around $55.37 \mathrm{~kg}(14.60 \%)$ in sapota. The maximum loss was found to occur at the retail level.
\end{abstract}

KEY WORDS : Farmers, Fruits, Market functionaries, Post-harvest losses

How to cite this paper : Mitrannavar, D.H. and Yeledalli, R.A. (2014). Estimation of post-harvest losses of major fruits in Karnataka- A management appraisal. Internat. J. Proc. \& Post Harvest Technol., 5 (2) : 179-183. 